J. Gen. Appl. Microbiol., 50, 79-90 (2004)

Full Paper

\title{
Isolation and characterization of lactobacilli from some traditional fermented foods and evaluation of the bacteriocins
}

\author{
Marilingappa Jamuna and Kadirvelu Jeevaratnam* \\ Biochemistry and Nutrition Discipline, Defence Food Research Laboratory, Siddarthanagar, Mysore-570011, India
}

(Received May 26, 2003; Accepted April 7, 2004)

\begin{abstract}
Lactic acid bacteria (LAB) commonly used in food as starter cultures are known to produce antimicrobial substances such as bacteriocins and have great potential as food biopreservatives. LAB isolated from traditional fermented foods (appam batter and pickles) were screened for bacteriocin production. Two lactobacilli, LABB and LABP (one from each source) producing bacteriocins were characterized. Both the bacilli were homo-fermentative, catalase negative and microaerophilic in nature. LABB was found to be a thermobacterium growing at $45^{\circ} \mathrm{C}$ while LABP was a streptobacterium growing at $15^{\circ} \mathrm{C}$. Both were able to grow at pH 4.5-8.6 but were intolerant to high salt concentration. They failed to produce gas from glucose as well as ammonia from arginine. Among the sugars examined they could not ferment arabinose, raffinose, rhamnose or xylose. Additionally, LABB could not ferment esculin, gluconate or mannose. LABB is identified as Lactobacillus acidophilus while LABP as $L b$. casei. Their bacteriocins showed a broad inhibitory spectrum against the indicator organisms tested. They were active below pH 8.0 and after autoclaving as well. There was a complete loss of activity when treated with proteolytic enzymes such as trypsin indicating the proteinaceous nature of the active molecules. SDS-PAGE of partially purified bacteriocins indicated the molecular mass of the bacteriocin as 3.8 and $4.5 \mathrm{kDa}$ for LABB and LABP respectively.
\end{abstract}

Key Words_—bacteriocins; characterization; fermented foods; lactic acid bacteria; Lactobacillus acidophilus; Lactobacillus casei

Introduction

Mankind has exploited lactic acid bacteria (LAB) for thousands of years for the production of fermented foods because of their ability to produce desirable changes in taste, flavor and texture as well as inhibit pathogenic and spoilage microorganisms. Since they are involved in numerous food fermentations known to man for millennia, it is assumed that most representatives of this group do not pose any health risk to man,

\footnotetext{
* Address reprint requests to: Dr. K. Jeevaratnam, Biochemistry and Nutrition Discipline, Defence Food Research Laboratory, Siddarthanagar, Mysore-570011, India.

E-mail: dfoodlab@sancharnet.in
}

and are designated as GRAS (generally recognized as safe) organisms. The LAB, generally considered as 'food grade' organisms, show special promise for selection and implementation as protective cultures. There are many potential applications of protective cultures in various food systems (Holzapfel et al., 1995). These organisms have been isolated from grains, dairy and meat products, fermenting vegetables, and the mucosal surfaces of animals (Lindgren and Dobrogosz, 1990). Different antimicrobials, such as lactic acid, acetic acid, hydrogen peroxide, carbon dioxide and bacteriocins, produced by these bacteria, can inhibit pathogenic and spoilage microorganisms, extending the shelf-life and enhancing the safety of food products (Aymerich et al., 2000). 
The discovery of nisin, the first bacteriocin used on a commercial scale as a food preservative dates back to the first half of last century but research on bacteriocins of $L A B$ has expanded in the last two decades, searching for novel bacteriocin-producing strains from dairy, meat and plant products, and traditional fermented products. Many bacteriocins have been isolated and characterized (Cleveland et al., 2001). Bacteriocins of $L A B$ are considered as safe natural preservatives or biopreservatives, as it is assumed that they are degraded by the proteases in the gastrointestinal tract (Cleveland et al., 2001). Bacteriocins are extracellularly released peptides or protein molecules, with a bactericidal or bacteriostatic mode of action against closely related species. The inhibitory spectrum of some bacteriocins also includes food spoilage and/or food-borne pathogenic microorganisms (Schillinger et al., 1996). In the past few years several bacteriocins associated with LAB have been reported, and some have been extensively characterized. In recent years, Listeria monocytogenes, an emerging pathogen has caused severe illness from food ingestion and this has drawn the attention of several investigators to focus their studies on the antilisteria activity of bacteriocins from lactobacilli (Aymerich et al., 2000; Messens and De Vuyst, 2002). In the present study, the LAB organisms isolated from traditional Indian fermented foods such as apam batter and vegetable pickle were screened for bacteriocin production, of which the two lactobacilli strains (one from each source) were characterized. The isolation, partial purification and characterization of the bacteriocins from these bacilli have also been described.

\section{Materials and Methods}

Chemicals. Analytical grade chemicals and dyes were obtained either from SRL, India or SD Fine Chemicals, India while proteolytic enzymes, molecular weight markers and bacteriological media were obtained from Sigma, USA and Hi-Media, India respectively.

The indicator organisms, viz., Enterococcus faecalis, Lactobacillus brevis, Lactococcus cremoris, Lactobacillus delbrueckii, Lactobacillus fermentum, Lactobacillus plantarum, Lactobacillus rhamnosus, Lactococcus diacetylactis, Lactococcus lactis, Leuconostoc mesenteroides, Bacillus cereus, Bacillus licheniformis, Bacillus subtilis, Clostridium perfringens, Listeria monocytogenes, Micrococcus luteus, Staphylococcus aureus, Aeromonas hydrophilus and Vibrio parahaemolyticus were procured from Microbial Type Culture Collection (MTCC) at Institute of Microbial Technology, Chandigarh, India, while Pediococcus acidilactici, Pediococcus cerevisiae and Pediococcus pentosaceus were procured from National Collection of Industrial Microorganisms (NCIM) at National Chemical Laboratory, Pune, India, and the remaining Pediococcus halophilus, Pediococcus pentosaceus, Escherichia coli and Pseudomonas were the isolates at Defence Food Research Laboratory, Mysore, India, denoted as DFR.

Isolation and screening of lactic acid bacteria for antimicrobial activity. $\mathrm{LAB}$ were isolated from the appam batter and vegetable pickle by appropriate dilutions with saline, plated on MRS agar and incubated anaerobically at $37^{\circ} \mathrm{C}$ for $2-3$ days. The well-isolated colonies were picked up and transferred to MRS broth. They were propagated twice and streaked on MRS agar to check the purity of the isolates and then stored in MRS agar overlaid with $50 \%$ glycerol at $-20^{\circ} \mathrm{C}$. A total of 25 isolates from appam batter and 10 isolates from pickle, all being Gram positive and catalase negative were tested for their ability to produce bacteriocins. The isolates maintained in frozen stocks were propagated twice in MRS broth and used for further study. These were inoculated into TGE broth and incubated at $37^{\circ} \mathrm{C}$ for $48 \mathrm{~h}$. Cell free supernatants adjusted to $\mathrm{pH} 5.0$ with $2 \mathrm{~N} \mathrm{NaOH}$, were concentrated to one tenth of the original volume by a flash evaporator. These were sterilized by passing through a $0.22 \mu \mathrm{m}$ membrane filter (Millipore, India) and were evaluated for antimicrobial activity by the agar well diffusion method (Tagg and McGiven, 1971) against Bacillus cereus, Staphylococcus aureus and Listeria monocytogenes. Ten isolates from appam batter showed promising antimicrobial activity, out of which nine were cocci and one a bacillus. Only one isolate from pickle, a bacillus showed antimicrobial activity. Both the bacilli, one each from appam batter (LABB) and pickle (LABP) were chosen for further study.

Physiological and biochemical tests. Growth was assayed in MRS broth at 15,37 and $45^{\circ} \mathrm{C}$ and $\mathrm{pH}$ of $3.9,4.5$ and 8.6 incubated at $37^{\circ} \mathrm{C}$. Salt tolerance was tested with $6.5 \%$ and $10 \%(\mathrm{w} / \mathrm{v}) \mathrm{NaCl}$. Production of acid and $\mathrm{CO}_{2}$ from glucose was tested in MRS broth containing Durhams tube, with citrate omitted (Schillinger and Lucke, 1987) and in Gibson's semi- 
solid tomato-juice medium by the method of Gibson and Abd-el-Malek (Harrigan, 1998). Production of ammonia in MRS broth omitting glucose and meat extract, but containing $0.3 \%$ arginine and $0.2 \%$ sodium citrate replacing ammonium citrate, was monitored using Nessler's reagent. Homo- and hetero-fermentative differentiation tests were also carried out according to the method reported by Zuniga et al. (1993). The effect of acetate on growth was tested in Rogosa agar medium adjusted to $\mathrm{pH} 5.6$ with acetic acid. Production of dextran from sucrose was monitored in MRS agar medium with $5 \%$ sucrose for 1-14 days against the control containing $0.1 \%$ sucrose. Production of acetoin from glucose was determined using VogesProskauer test-Barritt's modification (Harrigan, 1998). Ability to ferment various carbohydrates was done using MRS broth supplemented with filter sterilized sugar solutions to a final concentration of $0.5 \% \mathrm{w} / \mathrm{v}$ and $0.004 \%$ chlorophenol red without glucose or meat extract (Schillinger and Lucke, 1987). The configuration of lactic acid formed from glucose was determined enzymatically using D-lactate and L-lactate dehydrogenase.

Effect of cultivation conditions on growth and optimization of bacteriocin production. To study the optimum incubation time and temperature for the maximum production of bacteriocins, a series of $250 \mathrm{ml}$ unbuffered TGE broths, pH 6.5 were inoculated with 1\% $\mathrm{v} / \mathrm{v}$ of young cultures of the strains under study and incubated at $37^{\circ} \mathrm{C}$ for periods of $6,12,18,24,36,48$ and $72 \mathrm{~h}$. At the end of incubation period, cultures were examined for viable $L A B$ counts, $\mathrm{pH}$ and antibacterial activity. Another set of TGE flasks were incubated for $48 \mathrm{~h}$ at various temperatures, i.e. $30,37,42$ and $52^{\circ} \mathrm{C}$. Enumeration of viable $\mathrm{LAB}$ counts was carried out by pour plating of tenfold serial dilutions of samples on Lactobacillus MRS agar and incubated at $37^{\circ} \mathrm{C}$ for $48 \mathrm{~h}$. The $\mathrm{pH}$ of the culture media was recorded by handy $\mathrm{pH}$ scan while the antibacterial activity of partially purified preparation (by cold acetone precipitation as described below) was determined by the agar well diffusion method (Tagg and McGiven, 1971) using Staphylococcus aureus as the indicator organism. The bacteriocin preparations were serially diluted in the ratio of $1: 1,1: 2,1: 4,1: 6,1: 8$, etc., for quantification purpose. Seventy-five microliters of diluted sample was loaded to the wells of Trypticase soya agar $(0.75 \%)$ plates, seeded with an overnight culture of test organism at a concentration of
$10^{7} \mathrm{CFU} / \mathrm{ml}$. The plates were incubated at either 30 or $37^{\circ} \mathrm{C}$ for $16-18 \mathrm{~h}$ after pre-incubation at $4^{\circ} \mathrm{C}$ for $4 \mathrm{~h}$ and were examined for zones of inhibition around the wells. The reciprocal of the greatest inhibitory (last serial) dilution yielding definite inhibition zone of at least $2 \mathrm{~mm}$ excluding the diameter of the well was used to calculate arbitrary activity units (AU) per milliliter (Rekhif et al., 1994; Suma et al., 1998).

Partial purification and characterization of bacteriocins. (i) Cold-acetone extraction technique: Cell free supernatant-concentrate from 1-L TGE broth culture maintained at $<0^{\circ} \mathrm{C}$ was subjected to ice-cold acetone extraction (Scopes, 1984). Gently ice-cold acetone was added with constant stirring to a saturation of $60 \%$ and incubated for $10 \mathrm{~min}$ at $<0^{\circ} \mathrm{C}$. The acetone extract of bacteriocins obtained after centrifugation in a Sorvall refrigerated centrifuge was subjected to rotary vacuum evaporation to remove acetone. Later, the preparation was adjusted to $\mathrm{pH} 5.0$ after dialyzing in a dialysis bag of $2 \mathrm{kDa} \mathrm{MW}$ cut off (Sigma) overnight in cold room and used to determine the antimicrobial spectrum by evaluating antimicrobial activity against various LAB, Gram-positive and Gramnegative pathogens (as given in Table 3 ). The bacteriocin activity was expressed in terms of $\mathrm{AU} / \mathrm{ml}$, determined and calculated as described above while the specific activities of the bacteriocin preparations were represented as $A U$ per milligram of protein (AU/mg protein).

The above preparation was further subjected to $80 \%$ acetone precipitation, wherein the precipitate was reconstituted in distilled water and the residual acetone was removed by rotary vacuum evaporation. This bacteriocin preparation was subjected to dialysis using $2 \mathrm{kDa}$ MW cut off (Sigma) overnight in a cold room and the activity was determined after adjusting the $\mathrm{pH}$ to 5.0 as described above against $S$. aureus as the indicator organism.

(ii) Cell adsorption-desorption technique: Isolation of bacteriocins from broth cultures of isolates was carried out by the cell adsorption-desorption technique described by Yang et al. (1992) with slight modifications. One liter of culture media of each isolate $(48 \mathrm{~h})$ was heated at $70^{\circ} \mathrm{C}$ for $20 \mathrm{~min}$ to inactivate proteases and later adjusted to $\mathrm{pH} 6.5$ with $2 \mathrm{~N} \mathrm{NaOH}$ and allowed to adsorb onto the cells by continuous stirring on a magnetic stirrer for $2 \mathrm{~h}$. The cells were pelleted and washed with $5 \mathrm{~mm}$ sodium phosphate buffer of $\mathrm{pH}$ 6.5 and the bacteriocins were desorbed into $0.1 \mathrm{~N}$ 
$\mathrm{NaCl}, \mathrm{pH} 2.5$ by stirring overnight under cold conditions. The preparation was boiled at $60-70^{\circ} \mathrm{C}$ for 5-8 min prior to centrifugation. The $\mathrm{pH}$ of the supernatant was adjusted to 5.0 and concentrated to determine the bacteriocin activity as described above. This preparation was further purified using an Amicon centrifugal filter unit of MW cut off $5 \mathrm{kDa}$ (Centricon Plus80) to remove the broth proteins of higher MW and subsequently a dialysis bag of $2 \mathrm{kDa} M W$ cut off (Sigma) overnight in cold room to remove lower MW borth peptides for determination of MW of those bacteriocins by Tris-tricine SDS-PAGE as described below.

Gel permeation chromatography (GPC). A column $(110 \times 1.5 \mathrm{~cm})$ was packed with Sephadex G-50 Fine powder swollen in distilled water for $48 \mathrm{~h}$ and equilibrated with ammonium acetate buffer, $\mathrm{pH} 4.8$ and the same was used to elute the sample. Void volume was determined by passing blue dextran $(2,000 \mathrm{kDa})$ through the column. The above partially purified bacteriocin preparations obtained from cell adsorption and desorption technique were loaded to the column $2 \mathrm{ml}$ at a time. Fractions were collected about one and half of the bed volume at the flow rate of $0.2 \mathrm{ml} / \mathrm{min}$ at $5 \mathrm{~min}$ intervals and were read at $280 \mathrm{~nm}$ in spectrophotometer. Various fractions around peaks, shoulder and valley were pooled separately and examined for antimicrobial activity against indicator organism $S$. aureus. The specific activity and recovery were also determined using the active fractions. Subsequently, these active fractions were pooled and again run through the column for further purification for use to verify the antimicrobial activity against Gram-negative organisms.

Protein assay. The protein was determined by modified Biuret method of Gornall et al. (1949) with bovine serum albumin (BSA) as standard.

Effect of bacteriocins on target cells in liquid medium. The effect of bacteriocins on target cells in liquid medium was determined by deducing the killing or growth inhibition of the indicator organism. Various concentrations of the acidocin and caseicin were added to the indicator strain $S$. aureus $\left(10^{6} \mathrm{CFU} / \mathrm{ml}\right)$ inoculated in TSB broth and incubated at $37^{\circ} \mathrm{C}$. The optical density at $600 \mathrm{~nm}$ and viable cell count were monitored periodically at $0,4,8$ and $24 \mathrm{~h}$. Indicator cells without bacteriocins were used as experimental controls.

Effect of various treatments on antibacterial activity of the bacteriocins. The influence of enzymes, heat and $\mathrm{pH}$ on the physico-chemical properties of partially purified bacteriocins was studied. Bacteriocin preparations were treated with trypsin, protease, amylase and catalase at a concentration of $3 \mathrm{mg} / \mathrm{ml}$. The effect of heat was assessed at temperatures of 80,90 and $100^{\circ} \mathrm{C}$ for 30 and $60 \mathrm{~min}$ in a thermostatic water bath and at $121^{\circ} \mathrm{C}$ (autoclaved) for $15 \mathrm{~min}$. The effect of $\mathrm{pH}$ was tested by adjusting the $\mathrm{pH}$ in the range of 3.0-8.0 and examining for activity after incubation at 2, 4 and $24 \mathrm{~h}$. After the above treatments, bacteriocin activity was determined with or without adjusting the $\mathrm{pH}$ to 5.0 against $S$. aureus. Controls were also maintained without any treatment.

SDS-PAGE analysis. The Tris-tricine method of SDS-PAGE electrophoresis (Schagger and Von Jagow, 1987) was employed to determine the molecular weight of the antimicrobial peptides. It was performed in a vertical slab gel apparatus with stacking gel containing $6 \%$ acrylamide and $0.5 \%$ bisacrylamide, spacer gel of $10 \%$ acrylamide and $0.5 \%$ bisacrylamide and separating gel containing $16 \%$ acrylamide and $0.5 \%$ bisacrylamide. Electrophoresis of the bacteriocin preparation by cell adsorption-desorption technique and molecular weight markers was carried out at $50 \mathrm{~V}$. Gels were cut into two halves and one half was stained with Coomassie brilliant blue $\mathrm{G}$ while the other half was subjected to bioassay against $S$. aureus (Bhunia and Johnson, 1992). The molecular weights of the sample peptides were calculated from the relative mobility of the standard molecular weight markers run simultaneously.

\section{Results}

\section{Identification to lactic acid bacteria}

The data on phenotypic, physiological and biochemical characterization of the isolates are provided in Table 1. Both LABB and LABP did not produce either gas from glucose or ammonia from arginine. They are homofermentative. LABB is a thermobacterium while LABP a streptobacterium. Among the sugars examined, LABB could not ferment esculin, gluconate or mannose as compared to LABP while ribose was a poor substrate for LABB. However, both were unable to utilize arabinose, raffinose, rhamnose and xylose. Based on their ability to grow at $45^{\circ} \mathrm{C}$ (LABB) and $15^{\circ} \mathrm{C}$ (LABP) and ferment various sugars (Table 1) as well as the configuration of lactic acid produced, it is concluded that LABB is Lactobacillus acidophilus while 
Table 1. Morphological, physiological and biochemical characterization of LABB and LABP.

\begin{tabular}{|c|c|c|c|}
\hline \multicolumn{2}{|c|}{ Characteristics } & LABB & LABP \\
\hline \multicolumn{2}{|l|}{ Morphology } & Rod & Rod \\
\hline \multirow[t]{3}{*}{ Growth at } & $15^{\circ} \mathrm{C}$ & - & + \\
\hline & $37^{\circ} \mathrm{C}$ & ++ & ++ \\
\hline & $45^{\circ} \mathrm{C}$ & + & - \\
\hline \multirow[t]{3}{*}{$\mathrm{pH}$} & 3.9 & - & w \\
\hline & 4.4 & + & + \\
\hline & 8.6 & ++ & ++ \\
\hline \multirow[t]{2}{*}{ Salt (NaCl) } & $6.5 \%$ & w & w \\
\hline & $10 \%$ & - & - \\
\hline \multicolumn{2}{|c|}{$\mathrm{CO}_{2}$ from glucose } & - & - \\
\hline \multicolumn{2}{|c|}{$\mathrm{NH}_{3}$ from arginine } & - & - \\
\hline \multicolumn{2}{|c|}{ HHD medium } & $\mathrm{Ho}$ & Ho \\
\hline \multicolumn{4}{|c|}{ Carbohydrate fermentation } \\
\hline \multicolumn{2}{|c|}{ Arabinose } & - & - \\
\hline \multicolumn{2}{|l|}{ Cellobiose } & + & + \\
\hline \multicolumn{2}{|l|}{ Esculin } & - & + \\
\hline \multicolumn{2}{|l|}{ Fructose } & + & + \\
\hline \multicolumn{2}{|c|}{ Galactose } & + & + \\
\hline \multicolumn{2}{|c|}{ Gluconic acid } & - & + \\
\hline \multicolumn{2}{|c|}{ Inulin } & w & w \\
\hline \multicolumn{2}{|l|}{ Lactose } & + & + \\
\hline \multicolumn{2}{|l|}{ Maltose } & + & + \\
\hline \multicolumn{2}{|l|}{ Mannitol } & + & + \\
\hline \multicolumn{2}{|l|}{ Mannose } & - & + \\
\hline \multicolumn{2}{|l|}{ Mellibiose } & + & + \\
\hline \multicolumn{2}{|c|}{ Raffinose } & - & - \\
\hline \multicolumn{2}{|c|}{ Rhamnose } & - & - \\
\hline \multicolumn{2}{|c|}{ Ribose } & w & + \\
\hline \multicolumn{2}{|l|}{ Salicin } & + & + \\
\hline \multicolumn{2}{|l|}{ Sorbitol } & + & + \\
\hline \multicolumn{2}{|l|}{ Sucrose } & + & + \\
\hline \multicolumn{2}{|l|}{ Trehalose } & + & + \\
\hline \multicolumn{2}{|c|}{ Xylose } & - & - \\
\hline \multicolumn{2}{|c|}{ Lactic acid configuration } & $\mathrm{DL}$ & DL \\
\hline
\end{tabular}

$(++)$ Luxurious growth, $(+)$ growth, (w) weak growth, $(-)$ no growth, (Ho) homo-fermentative.

\section{LABP is Lactobacillus casei.}

Effect of cultivation conditions on growth and optimization of bacteriocin production

Bacteriocin production of both the isolates not only depended on the bacterial growth phase but also on the temperature and initial $\mathrm{pH}$ values of the culture medium. Production of the inhibitory substance was detected in the late growth phase. The inhibitory activity against $S$. aureus was detected in a $12 \mathrm{~h}$ culture (a)

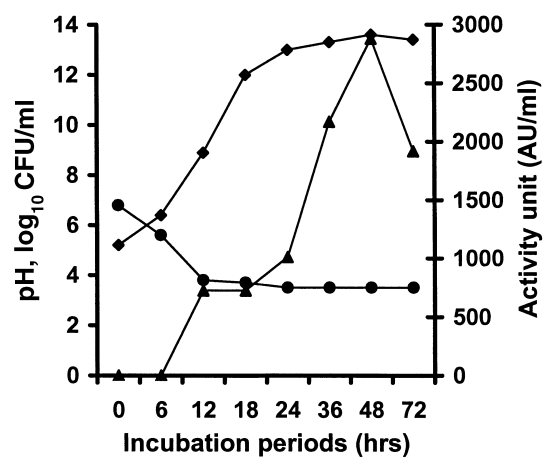

(b)

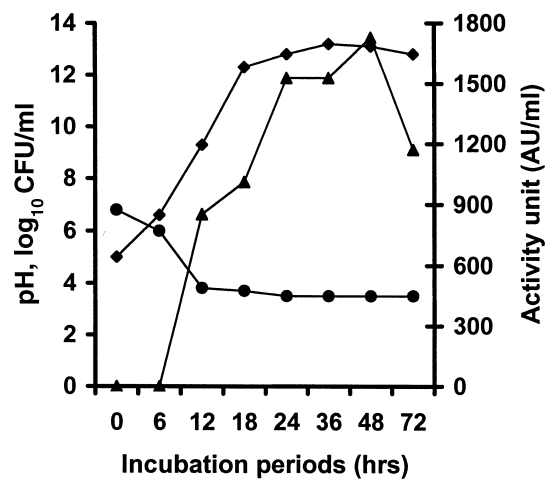

Fig. 1. Effect of duration of incubation at $37^{\circ} \mathrm{C}$ on the viable cell count $(\bullet), \mathrm{pH}(\bullet)$ and antibacterial activity $(\boldsymbol{\Delta})$ of [a] LABB and [b] LABP in TGE broth medium.

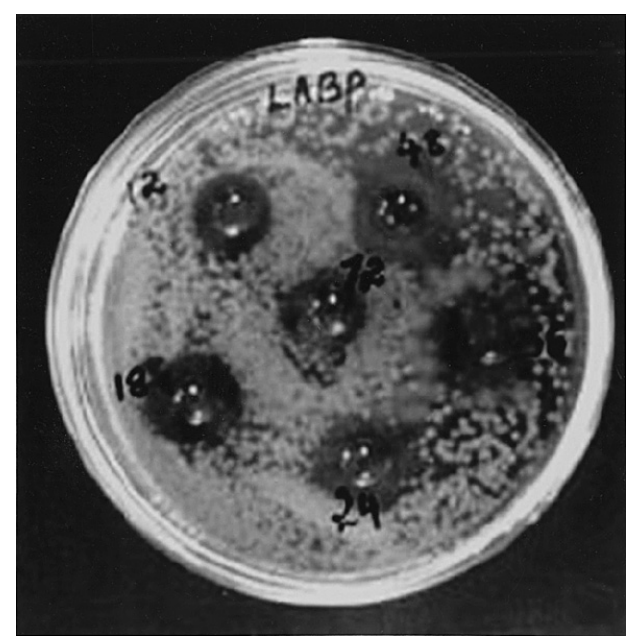

Fig. 2. Antimicrobial activity of bacteriocin preparation from LABP against $S$. aureus.

Cold acetone extract preparation at different incubation periods, viz., 12, 18, 24, 36, 48 and $72 \mathrm{~h}$.

having biomass of $8.9 \log _{10} \mathrm{CFU} / \mathrm{ml}$ of $\mathrm{LABB}$ and $9.3 \log _{10} \mathrm{CFU} / \mathrm{ml}$ of LABP when the $\mathrm{pH}$ of the cultures (both the strains) had dropped to 3.8 (Fig. 1). The bacteriocin concentration of LABB and LABP reached a 
Table 2. Effect of temperature on growth and bacteriocin production by LABB and LABP.

\begin{tabular}{|c|c|c|c|c|}
\hline \multirow{2}{*}{ Temperature $\left({ }^{\circ} \mathrm{C}\right)$} & \multicolumn{2}{|c|}{ Viable counts $\left(\log _{10} \mathrm{CFU} / \mathrm{ml}\right)^{a}$} & \multicolumn{2}{|c|}{ Antibacterial activity $(\mathrm{AU} / \mathrm{ml})^{a}$} \\
\hline & LABB & LABP & LABB & LABP \\
\hline 30 & $\begin{array}{c}10.2 \\
(9.8-10.5)\end{array}$ & $\begin{array}{c}11.3 \\
(10.7-12.1)\end{array}$ & $\begin{array}{c}993 \\
(853-1,333)\end{array}$ & $\begin{array}{c}1,724 \\
(1,333-1,920)\end{array}$ \\
\hline 37 & $\begin{array}{c}10.8 \\
(10.3-11.3)\end{array}$ & $\begin{array}{c}10.2 \\
(9.9-10.5)\end{array}$ & $\begin{array}{c}2,382 \\
(1,920-2,613)\end{array}$ & $\begin{array}{c}1,529 \\
(1,333-1,920)\end{array}$ \\
\hline 40 & $\begin{array}{c}12.1 \\
(11.3-12.6)\end{array}$ & $\begin{array}{c}9.2 \\
(8.7-10.0)\end{array}$ & $\begin{array}{c}2,880 \\
(2,613-3,413)\end{array}$ & $\begin{array}{c}391 \\
(213-480)\end{array}$ \\
\hline 52 & No growth & & & \\
\hline
\end{tabular}

${ }^{a}$ The values are means of 3 independent experiments performed in duplicate while the range is given in parentheses.

Table 3. Antibacterial spectrum of LABB and LABP by the agar well diffusion technique.

\begin{tabular}{|c|c|c|}
\hline \multirow{2}{*}{ Indicator strains } & \multicolumn{2}{|c|}{ Antimicrobial activity $(\mathrm{AU} / \mathrm{ml})^{a}$} \\
\hline & LABB & LABP \\
\hline \multicolumn{3}{|l|}{ Lactic acid bacteria } \\
\hline Enterococcus faecalis MTCC 2729 & $2,382(1,920-2,613)$ & $1,013(853-1,333)$ \\
\hline Lactobacillus brevis MTCC 1750 & $391(213-480)$ & $102(80-213)$ \\
\hline Lactobacillus delbrueckii MTCC 911 & $302(213-480)$ & $168(80-213)$ \\
\hline Lactobacillus fermentum MTCC 903 & $54(27-80)$ & $124(80-213)$ \\
\hline Lactobacillus plantarum MTCC 1746 & 0 & 0 \\
\hline Lactobacillus rhamnosus MTCC 1408 & $302(213-480)$ & $391(213-480)$ \\
\hline Lactococcus cremoris MTCC 1484 & $1,529(1,333-1,920)$ & $6,471(5,333-7,680)$ \\
\hline Lactococcus diacetylactis MTCC 3042 & $5,706(5,333-6,453)$ & $5,538(4,320-6,453)$ \\
\hline Lactococcus lactis MTCC 440 & $168(80-213)$ & $391(213-480)$ \\
\hline Lactococcus lactis MTCC 3041 & $124(80-213)$ & $62(27-80)$ \\
\hline LABB & 0 & $124(80-213)$ \\
\hline LABP & $54(27-80)$ & 0 \\
\hline Leuconostoc mesenteroides MTCC 107 & $1,093(853-1,333)$ & $604(480-853)$ \\
\hline Pediococcus acidilactici NCIM 2292 & $1,724(1,333-1,920)$ & $302(213-480)$ \\
\hline Pediococcus cerevisiae NCIM 2171 & $391(213-480)$ & $258(213-480)$ \\
\hline Pediococcus halophilus DFR JJ11 & $146(80-213)$ & $728(480-853)$ \\
\hline Pediococcus pentosaceus NCIM 2296 & $1,724(1,333-1,920)$ & $258(213-480)$ \\
\hline Pediococcus pentosaceus DFR JJ10 & $391(213-480)$ & $235(80-480)$ \\
\hline \multicolumn{3}{|l|}{ Other Gram-positive } \\
\hline Bacillus cereus MTCC $1272^{*}$ & $5,368(4,320-6,453)$ & $3,449(2,613-4,320)$ \\
\hline Bacillus licheniformis MTCC 429* & $728(480-853)$ & $1,013(853-1,333)$ \\
\hline Bacillus subtilis MTCC $441^{*}$ & $1,333(853-1,920)$ & $2,266(1,920-2,613)$ \\
\hline Clostridium perfringens MTCC 450 & $480(213-853)$ & $391(213-480)$ \\
\hline Clostridium sporogenes NCIM 2559 & $1,626(1,333-1,920)$ & $2,266(1,920-2,613)$ \\
\hline Listeria monocytogenes MTCC 657 & $1,724(1,333-1,920)$ & $2,649(1,920-3,413)$ \\
\hline Micrococcus luteus MTCC 2452 & $1,369(853-1,920)$ & $889(480-1,333)$ \\
\hline Staphylococcus aureus MTCC $737^{*}$ & $2,880(2,613-3,413)$ & $1,724(1,333-1,920)$ \\
\hline \multicolumn{3}{|l|}{ Gram-negative } \\
\hline Aeromonas hydrophilus MTCC 646 & $1,920(1,333-2,613)$ & $1,333(853-1,920)$ \\
\hline Escherichia coli DFR 262* & $213(80-480)$ & $2,266(1,920-2,613)$ \\
\hline Pseudomonas DFR 219* & $1,529(1,333-1,920)$ & $480(213-853)$ \\
\hline Vibrioparahaemolyticus MTCC 451 & $391(213-480)$ & $604(480-853)$ \\
\hline
\end{tabular}

${ }^{a}$ The values are means of 3 independent experiments performed in duplicate while the range is given in parentheses.

* These organisms were incubated at $30^{\circ} \mathrm{C}$ while others at $37^{\circ} \mathrm{C}$. 
maximum of $2,880 \mathrm{AU} / \mathrm{ml}$ and $1,724 \mathrm{AU} / \mathrm{ml}$ after $48 \mathrm{~h}$ of incubation (mid-stationary phase) at a viable cell count of 13.6 and $13.1 \log _{10} \mathrm{CFU} / \mathrm{ml}$ and $\mathrm{pH}$ of the cultures decreased to 3.7. On further incubation to $72 \mathrm{~h}$, there was a decrease in bacteriocin production (Fig. 2). Greater antibacterial activity was observed with LABB at $40^{\circ} \mathrm{C}$ while $\mathrm{LABP}$ showed at $30^{\circ} \mathrm{C}$ (Table 2); however, both the isolates failed to grow at $52^{\circ} \mathrm{C}$.

\section{Antibacterial spectrum}

The bacteriocin preparations $(60 \%$ ice-cold acetone extract) from these bacilli showed a broad inhibitory spectrum against a wide range of $L A B$ of different species and some food-borne pathogens and spoilage bacteria including Gram-negative $E$. coli and Pseudomonas (Table 3) whereas moderate inhibition was observed against Clostridium perfringens and Vibrio parahaemolyticus. However, neither isolate could inhibit the growth of Lactobacillus plantarum. The antibacterial spectrum verified using the GPC purified bacteriocins from these bacilli isolates is given in Table 4.

\section{Partial purification of bacteriocins}

The inhibitory activity, specific activity, yield and fold purification obtained during the partial purification of bacteriocins from LABB and LABP by two techniques have been summarized in Table 5 . Among the various levels of cold-acetone tried, the antimicrobial activity was observed in $60 \%$ extract or supernatant and in $80 \%$ precipitate. Ice-cold acetone (both 60 and $80 \%$ ) could remove major broth proteins of high MW above $10 \mathrm{kDa}$ and subsequent $2 \mathrm{kDa}$ cut off dialysis could provide a better yield by removing broth proteins below $2 \mathrm{kDa}$ without losing much of the bacteriocin while the other technique, cell adsorption-desorption, provided fairly pure bacteriocin preparations of very low yield. There was further loss in yield in the GPC purified preparation with enhanced specific activity. Further purification of these pooled active fractions by passing through the column once again led to a single active peak (Fig. 3).

\section{Effect of bacteriocins on target cells in liquid medium}

Figure 4 shows the effect of both the bacteriocins on the growth of $S$. aureus. In the case of control tube inoculated with indicator strain, but without bacteriocins, the viable cell count increased from $10^{6}$ to $10^{12} \mathrm{CFU} / \mathrm{ml}$ after $24 \mathrm{~h}$ incubation at $37^{\circ} \mathrm{C}$. Addition of the partially
Table 4. Antibacterial spectrum of GPC purified bacteriocins from $L A B B$ and LABP by the agar well diffusion technique.

\begin{tabular}{|c|c|c|}
\hline \multirow{2}{*}{ Indicator strains } & \multicolumn{2}{|c|}{ Antimicrobial activity } \\
\hline & LABB & LABP \\
\hline \multicolumn{3}{|l|}{ Lactic acid bacteria } \\
\hline Enterococcus faecalis MTCC 2729 & ++ & ++ \\
\hline Lactobacillus brevis MTCC 1750 & + & + \\
\hline Lactococcus cremoris MTCC 1484 & ++ & +++ \\
\hline Lactobacillus delbrueckii MTCC 911 & + & + \\
\hline Lactobacillus fermentum MTCC 903 & + & + \\
\hline Lactobacillus plantarum MTCC 1746 & - & - \\
\hline Lactobacillus rhamnosus MTCC 1408 & + & + \\
\hline Lactococcus diacetylactis MTCC 3042 & +++ & +++ \\
\hline Lactococcus lactis MTCC 440 & + & + \\
\hline Lactococcus lactis MTCC 3041 & + & + \\
\hline LABB & - & + \\
\hline LABP & + & - \\
\hline Leuconostoc mesenteroides MTCC 107 & ++ & + \\
\hline Pediococcus acidilactici NCIM 2292 & + & + \\
\hline Pediococcus cerevisiae NCIM 2171 & + & + \\
\hline Pediococcus halophilus DFR JJ11 & + & + \\
\hline Pediococcus pentosaceus NCIM 2296 & ++ & + \\
\hline Pediococcus pentosaceus DFR JJ10 & + & + \\
\hline \multicolumn{3}{|l|}{ Gram-positive } \\
\hline Bacillus cereus MTCC 1272* & +++ & +++ \\
\hline Bacillus licheniformis MTCC 429* & + & ++ \\
\hline Bacillus subtilis MTCC $441^{*}$ & + & +++ \\
\hline Clostridium perfringens MTCC 450 & ++ & ++ \\
\hline Clostridium sporogenes NCIM 2559 & ++ & +++ \\
\hline Listeria monocytogenes MTCC 657 & ++ & ++ \\
\hline Micrococcus luteus MTCC 2452 & ++ & ++ \\
\hline Staphylococcus aureus MTCC 737* & ++ & ++ \\
\hline \multicolumn{3}{|l|}{ Gram-negative } \\
\hline Aeromonas hydrophilus MTCC 646 & + & + \\
\hline Escherichia coli DFR 262* & + & + \\
\hline Pseudomonas DFR 219* & + & + \\
\hline Vibrio parahaemolyticus MTCC 451 & + & + \\
\hline
\end{tabular}

$(+++)$ Very good activity, $(++)$ good activity, $(+)$ moderate activity, (-) no activity.

* These organisms were incubated at $30^{\circ} \mathrm{C}$ while others at $37^{\circ} \mathrm{C}$.

purified bacteriocin (acetone extract) to the indicator strain inhibited the growth of the cells. The colony counts of the culture tubes treated with the bacteriocin concentrations of $2,880 \mathrm{AU} / \mathrm{ml} \mathrm{LABB}$ and $1,724 \mathrm{AU} / \mathrm{ml}$ LABP (undiluted) decreased from $6 \log _{10}$ to $3.5-$ $4.5 \log _{10}$. With bacteriocin concentrations of 1,440 $\mathrm{AU} / \mathrm{ml}$ and $862 \mathrm{AU} / \mathrm{ml}$ (1:1 diluted), initially there was a reduction in the growth, but after $24 \mathrm{~h}$, growth 
Table 5. Purification of bacteriocins from LABB and LABP isolates through acetone extraction and cell adsorption-desorption techniques.

\begin{tabular}{|c|c|c|c|c|c|c|}
\hline Treatment & $\begin{array}{l}\text { Total volume } \\
(\mathrm{ml})\end{array}$ & $\begin{array}{l}\text { Activity } \\
\text { (AU/ml) }\end{array}$ & $\begin{array}{c}\text { Protein } \\
\text { concentration } \\
(\mathrm{mg} / \mathrm{ml})\end{array}$ & $\begin{array}{l}\text { Specific } \\
\text { activity } \\
(\mathrm{AU} / \mathrm{mg})\end{array}$ & $\%$ Yield & $\begin{array}{c}\text { Fold } \\
\text { purification }\end{array}$ \\
\hline \multicolumn{7}{|l|}{ LABB } \\
\hline Cell free supernatant-concentrate & 100 & $\begin{array}{c}684 \\
(480-853)\end{array}$ & $\begin{array}{c}185 \\
(162-190)\end{array}$ & $\begin{array}{c}3.7 \\
(3.0-4.5)\end{array}$ & 100 & 1.0 \\
\hline Acetone extract $(60 \%)$ & 20 & $\begin{array}{c}2,897 \\
(1,920-3,413)\end{array}$ & $\begin{array}{c}107 \\
(84-110)\end{array}$ & $\begin{array}{c}27 \\
(23-31)\end{array}$ & $\begin{array}{c}84 \\
(80-86)\end{array}$ & $\begin{array}{c}7.3 \\
(6.2-8.4)\end{array}$ \\
\hline Acetone precipitate ( $80 \%)$ & 10 & $\begin{array}{c}4,337 \\
(3,413-5,333)\end{array}$ & $\begin{array}{c}131 \\
(125-160)\end{array}$ & $\begin{array}{c}33 \\
(27-35)\end{array}$ & $\begin{array}{c}63 \\
(57-73)\end{array}$ & $\begin{array}{c}8.9 \\
(7.3-9.5)\end{array}$ \\
\hline Cell adsorbed & 5 & $\begin{array}{c}728 \\
(480-853)\end{array}$ & $\begin{array}{c}5.9 \\
(4.5-6.7)\end{array}$ & $\begin{array}{c}123 \\
(107-142)\end{array}$ & $\begin{array}{c}5.3 \\
(3.5-6.7)\end{array}$ & $\begin{array}{c}33 \\
(29-38)\end{array}$ \\
\hline GPC purified fraction & 1 & $\begin{array}{c}1,560 \\
(1,023-1,828)\end{array}$ & $\begin{array}{c}2.6 \\
(2.3-2.8)\end{array}$ & $\begin{array}{c}580 \\
(445-653)\end{array}$ & $\begin{array}{c}2.3 \\
(1.5-2.7)\end{array}$ & $\begin{array}{c}162 \\
(120-176)\end{array}$ \\
\hline \multicolumn{7}{|l|}{ LABP } \\
\hline Cell free supernatant-concentrate & 100 & $\begin{array}{c}540 \\
(480-853)\end{array}$ & $\begin{array}{c}160 \\
(153-185)\end{array}$ & $\begin{array}{c}3.4 \\
(3.1-4.6)\end{array}$ & 100 & 1.0 \\
\hline Acetone extract $(60 \%)$ & 20 & $\begin{array}{c}1,724 \\
(853-1,920)\end{array}$ & $\begin{array}{c}89 \\
(82-92)\end{array}$ & $\begin{array}{c}19 \\
(17-21)\end{array}$ & $\begin{array}{c}64 \\
(36-71)\end{array}$ & $\begin{array}{c}5.6 \\
(5.4-6.2)\end{array}$ \\
\hline Acetone precipitate (80\%) & 10 & $\begin{array}{c}3,013 \\
(2,613-3,413)\end{array}$ & $\begin{array}{c}112 \\
(106-118)\end{array}$ & $\begin{array}{c}27 \\
(24-29)\end{array}$ & $\begin{array}{c}56 \\
(54-57)\end{array}$ & $\begin{array}{c}8.0 \\
(7.0-8.5)\end{array}$ \\
\hline Cell adsorbed & 5 & $\begin{array}{c}604 \\
(480-853)\end{array}$ & $\begin{array}{c}4.6 \\
(4.2-6.0)\end{array}$ & $\begin{array}{c}131 \\
(114-142)\end{array}$ & $\begin{array}{c}5.6 \\
(4.4-7.8)\end{array}$ & $\begin{array}{c}38 \\
(34-42)\end{array}$ \\
\hline GPC purified fraction & 1 & $\begin{array}{c}1,291 \\
(1,023-1,828)\end{array}$ & $\begin{array}{c}1.9 \\
(1.6-2.8)\end{array}$ & $\begin{array}{c}679 \\
(634-731)\end{array}$ & $\begin{array}{c}2.4 \\
(1.8-3.3)\end{array}$ & $\begin{array}{c}200 \\
(186-215)\end{array}$ \\
\hline
\end{tabular}

The values are means of 3 independent experiments performed in duplicate while the range is given in parentheses.

increased gradually.

Effect of various treatments on antimicrobial activity of the bacteriocins

The bacteriocin preparations lost antimicrobial activity when treated with proteolytic enzymes but not with amylase and catalase (Fig. 5; Table 6). This indicated the proteinaceous nature of the bacteriocins. Bacteriocins from both the isolates are found to be thermostable (Table 6). The activity of bacteriocins from LABB and LABP persisted at levels in the range of $86 \%$ and $91 \%$ at $80^{\circ} \mathrm{C}$ (heated for $30 \mathrm{~min}$ and $1 \mathrm{~h}$ ) and $77 \%$ and $86 \%$ after autoclaving $\left(121^{\circ} \mathrm{C}\right.$ for $\left.15 \mathrm{~min}\right)$ respectively. However, a loss in activity in the ranges of $48 \%$ and $58 \%$ in the case of $L A B B$ and $31 \%$ and $47 \%$ in the case of $L A B P$ was observed when heated at $100^{\circ} \mathrm{C}$ for $30 \mathrm{~min}$ and $1 \mathrm{~h}$ respectively. Bacteriocin from LABP was more heat stable than that from LABB. Table 6 shows the influence of $\mathrm{pH}$ on the bacteriocin activity from both the isolates. The bacteriocin activity per- sisted at $\mathrm{pH}$ in the range of 3.0 to 8.0 in both $\mathrm{LABB}$ and LABP after $24 \mathrm{~h}$ incubation. However, there was a loss in activity of LABB bacteriocin by about $22 \%$ and LABP by $26 \%$ at $\mathrm{pH} 8.0$ after $24 \mathrm{~h}$ of incubation when the $\mathrm{pH}$ of the samples was brought back to $\mathrm{pH} 5.0$. However, there was considerable loss of activity in these samples $(24 \mathrm{~h})$ above $\mathrm{pH} 6.0$ tested as such without adjusting the $\mathrm{pH}$ to 5.0 .

\section{SDS-PAGE analysis}

The Tris-tricine SDS-PAGE electrophoresis of the bacteriocin preparations of both LABB and LABP from the cell adsorption-desorption technique showed multiple bands on account of the presence of broth proteins along with the bacteriocins in the electrophoretogram (data not shown). Subsequent to ultrafiltration using $5,000 \mathrm{MW}$ cut off and dialysis using $2 \mathrm{kDa}$ cut off, these bacteriocin preparations showed a single protein band with a MW of 3.8 and 4.5 for LABB and LABP respectively as determined by relative mobility in com- 
(a)

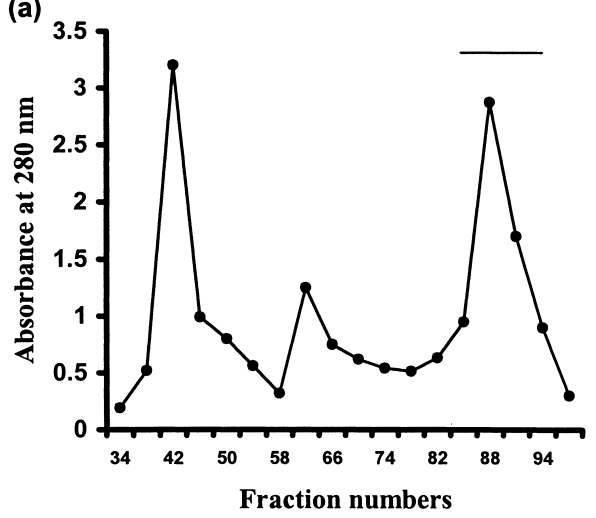

(b)

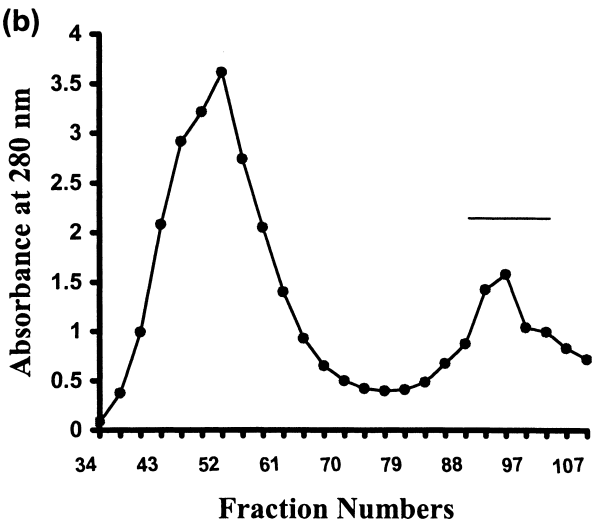

Fig. 3. Purification of bacteriocins by Sephadex G-50 column.

Absorbance at $280 \mathrm{~nm}(\bullet)$. [a] LABP, active fractions 86-94 indicated by the bar (-); [b] LABB, active fractions $88-100$ indicated by the bar (-).

parison to MW standards (Fig. 6a). The authenticity of the purified peptides as a bacteriocin was confirmed by the inhibitory zone observed with the gel half overlaid with an indicator organism (Fig. 6b).

\section{Discussion}

The lactic acid bacteria generally considered as 'food grade' organisms, showed special promise for selection and implementation as protective cultures. The use of bacteriocinogenic starter/protective cultures could improve the quality and increase safety by inhibiting the food-borne pathogens and spoilage microorganisms. Recent outbreaks of emerging pathogens such as Listeria monocytogenes causing severe illness through food ingestion have prompted the scientific community to focus their studies on the anti-listeria activity of bacteriocins produced by lactobacilli and Pediococcus strains (Aymerich et al., 2000; (a)

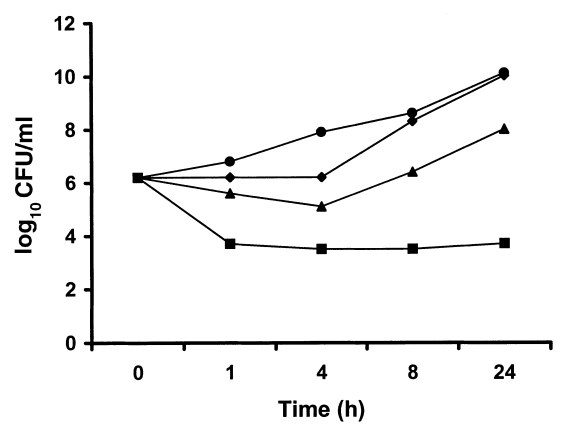

(b)

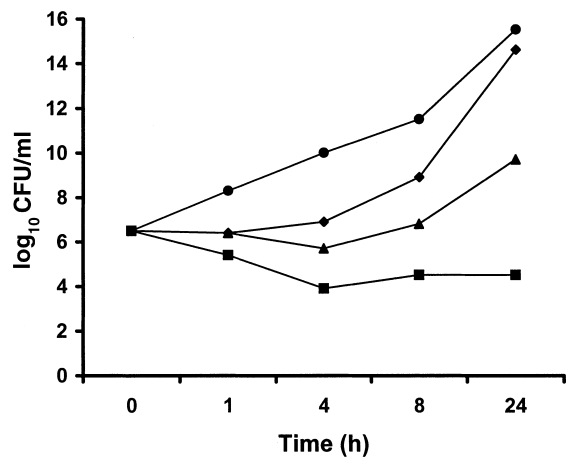

Fig. 4. Effect of varied concentration of bacteriocins $(\mathrm{AU} / \mathrm{ml})$ on cultures of $S$. aureus.

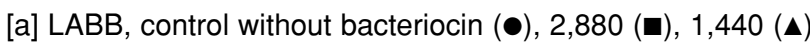
and $720(\bullet)$; [b] LABP, control without bacteriocin $(\bullet), 1,724$ $(\square), 862(\Delta)$ and $431(\bullet)$.

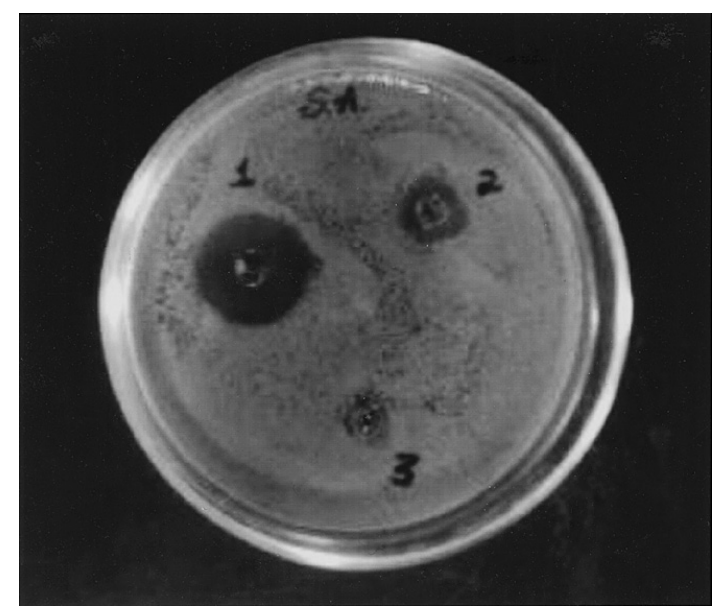

Fig. 5. Antimicrobial activity of bacteriocin preparation from LABP against $S$. aureus.

Cell adsorbed-desorbed preparation: 1, undiluted; 2, 1 in 10 diluted; 3 , protease $(3 \mathrm{mg} / \mathrm{ml})$ treated.

Messens and De Vuyst, 2002; Todorov et al., 1999). In the present study, the bacteriocins from the lactobacilli isolated from both appam batter and vegetable pickle have shown a broad-spectrum antimicrobial activity in- 


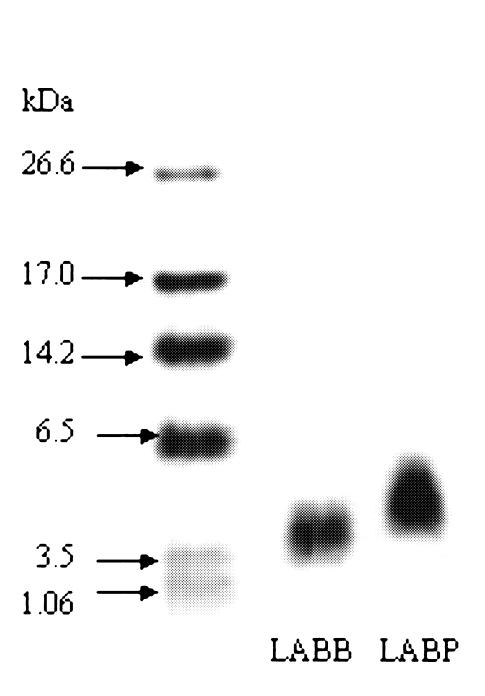

(a)

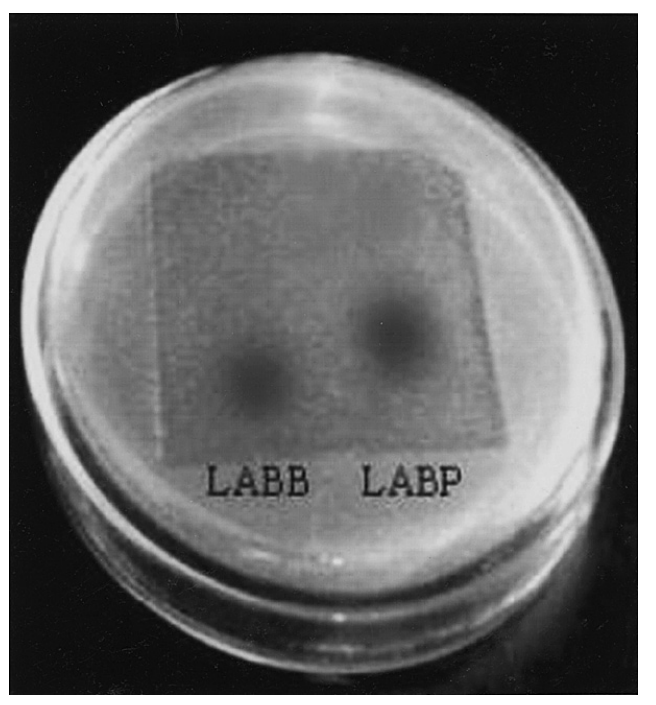

(b)

Fig. 6. (a) Tris-tricine SDS-PAGE of partially purified bacteriocins from cell adsorbed-desorbed preparations from both LABB and LABP along with the standard MW markers; (b) SDS-PAGE gel half showing the zone of inhibition of $S$. aureus by the bacteriocins.

Table 6. The effect of enzymes, heat treatment and pH on the bacteriocins of acetone extract from the isolates.

\begin{tabular}{llcc}
\hline & & \multicolumn{2}{c}{$\begin{array}{c}\text { Residual antibacterial activity } \\
(\%)^{a}\end{array}$} \\
\cline { 2 - 4 } Treatment & & LABB & LABP \\
& & & 100 \\
Enzymes & Amylase & 100 & 100 \\
& Catalase & 100 & $15(10-21)$ \\
& Trypsin & $12(10-14)$ & negligible \\
Temperature & Protease & negligible & $92(88-94)$ \\
& $80^{\circ} \mathrm{C}(30 \mathrm{~min})$ & $86(75-88)$ & $96(75-88)$ \\
& $80^{\circ} \mathrm{C}(60 \mathrm{~min})$ & $84(75-88)$ & $86(73-87)$ \\
& $90^{\circ} \mathrm{C}(30 \mathrm{~min})$ & $67(63-75)$ & 80 (73) \\
& $90^{\circ} \mathrm{C}(60 \mathrm{~min})$ & $65(63-75)$ & $75(73-87)$ \\
& $100^{\circ} \mathrm{C}(30 \mathrm{~min})$ & $52(50-63)$ & $69(58-75)$ \\
& $100^{\circ} \mathrm{C}(60 \mathrm{~min})$ & $42(38-50)$ & $53(50-58)$ \\
& 3.0 to 7.0 & 100 & 100 \\
& 8.0 & $78(73-87)$ & $74(71-86)$ \\
& & & \\
\hline
\end{tabular}

\footnotetext{
${ }^{a}$ The values are means of 3 independent experiments performed in duplicate while the range is given in parentheses. The activities of untreated samples are 2,880 and $1,724 \mathrm{AU} / \mathrm{ml}$ for LABB and LABP respectively.
}

cluding considerabe anti-listeria activity. Based on their ability to grow at $45^{\circ} \mathrm{C}(\mathrm{LABB})$ and $15^{\circ} \mathrm{C}(\mathrm{LABP})$, and to ferment various sugars (Table 1) and the configuration of lactic acid produced, it was determined that the lactobacillus from appam batter is $L b$. acidophilus while that from pickle is $L b$. casei. Growth and production experiments indicated that bacteriocin production starts in the late log phase as observed by others (Ahn and Stiles, 1990; van Laack et al., 1992), and attains a maximum at mid stationary phase.

The cold acetone extraction followed by dialysis was found to be the most suitable to obtain partially purified bacteriocins, since better recovery, specific activity and fold purification could be achieved (Table 5) than that obtained from cell adsorption-desorption technique developed by Yang et al. (1992). However, in spite of very low recovery, the cell adsorption-desorption method has provided fairly pure preparations useful for further characterization. Generally, the bacteriocins from $L A B$ were shown to be ineffective against Gramnegative bacteria. The partially purified bacteriocin preparations by cold acetone extraction from both the strains showed broad antimicrobial activity including against Gram-negative Pseudomonas and E. coli strains (Table 3), which has been verified using the GPC purified bacteriocin preparations of partially purified cell adsorption and desorption samples from both the strains (Table 4). Earlier, Suma et al. (1998) also reported the inhibitory action of bacteriocin of $L b$. plantarum against Gram-negative strains. These two bacteriocins appear to be unique and atypical in that their activity against the harmful Clostridium, Pseudomonas 
and $E$. coli is interesting and often desirable as the GPC purified bacteriocin preparation from these lactobacilli also showed antibacterial activity against these Gram-negative strains.

The inhibition kinetics using the bacteriocins from LABB and LABP (Fig. 4) indicated a bactericidal mode of action without causing cell lysis by a decrease in viable cells of indicator organism initially and subsequently increased towards the end of the experiment, similar to the observations made by $\mathrm{Du}$ Toit et al. (2000) with enterocins. Moreover, the optical density of the cell culture was not altered with time in the culture tube containing higher concentrations of bacteriocins. In comparison with earlier reports of others (Bhunia et al., 1988; Enan et al., 1996) the bactericidal effect was not rapid in our study. However, to state the bactericidal or bacteriostatic mode of action of the antimicrobials, several factors such as assay systems used, concentrations and purity of the inhibitor, the sensitivity of the indicator species, the density of the cell suspension used (Samelis et al., 1994) and the type of buffer or broth used need to be considered. In the present study, the use of broth instead of buffer (Enan et al., 1996) to study the killing kinetics, exhibited more of a bacteriostatic mode of action, probably due to an insufficient amount of bacteriocin to kill a large number of cells rapidly and thus suppress the growth.

The physico-chemical properties of bacteriocins from the two species were similar to those of the other bacteriocins of lactobacilli belonging to the group II lactic acid bacteria with respect to molecular weight, heat and $\mathrm{pH}$ stability, sensitivity to proteolytic enzymes (B. ten Brink et al., 1994). The initial bacteriocin preparations from the cell adsorption-desorption technique showed multiple bands on account of the presence of broth proteins along with the bacteriocins in the electrophoretogram of Tris-tricine SDS-PAGE (data not shown). However, the same preparations after ultrafiltration using 5,000 MW cut off and dialysis using $2 \mathrm{kDa}$ cut off showed a single band of bacteriocin (Fig. 6a) as confirmed by the inhibitory zone observed with the gel half overlaid with an indicator organism (Fig. 6b). The $3.8 \mathrm{kDa} \mathrm{MW}$ of the bacteriocin from LABB ( $L b$. acidophilus) is within the MW range of $2.5-5.0 \mathrm{kDa}$ reported by others for $L b$. acidophilus (B. ten Brink et al., 1994; Messens and De Vuyst, 2002; Muriana and Klaenhammer, 1991).

The isolated $L b$. acidophilus and $L b$. casei may be of much interest as probiotic strains since they were the genera of bacteria found to inhabit the Gl tract. Besides, the production of bacteriocins having a wide spectrum of antibacterial activity against Listeria, Clostridium and even Gram-negative Pseudomonas and $E$. coli to employ as biopreservatives, these $L b$. acidophilus and $L b$. casei may be of great interest as probiotic strains because of their ability to adhere to intestinal epithelial cells and being of human origin (Stiles and Holzapfel, 1997). The safety of these strains has been documented in experimental, clinical and epidemiological studies. Moreover, they are known to exhibit a stabilizing effect on gut permeability and suppression of allergic reactions in food hypersensitivity (Saxelin, 1997).

\section{Acknowledgments}

The authors are thankful to Dr. A. S. Bawa, Director, DFRL, Mysore, for providing the facilities. Ms. M. Jamuna is also grateful to Defence Research and Development Organization, New Delhi, for offering a research fellowship and financial assistance.

\section{References}

Ahn, C. and Stiles, M. E. (1990) Plasmid associated bacteriocin production by a strain of Carnobacterium piscicola from meat. Appl. Environ. Microbiol., 56, 2503-2510.

Aymerich, M. T., Garriga, M., Monfort, J. M., Nes, I., and Hugas, M. (2000) Bacteriocin-producing lactobacilli in Spanishstyle fermented sausages: Characterization of bacteriocins. Food Microbiol., 17, 33-45.

Bhunia, A. K. and Johnson, M. G. (1992) A modified method to directly detect in SDS-PAGE the bacteriocin of Pediococcus acidilactici. Lett. Appl. Microbiol., 41, 84-89.

Bhunia, A. K., Johnson, M. C., and Ray, B. (1988) Purification, characterization and antimicrobial spectrum of a bacteriocin produced by Pediococcus acidilactici. J. Appl. Bacteriol., 65, 261-268.

B. ten Brink, Minekus, M., van der Vossen, J. M. B. M., Leer, R. J., and Huisin't Veld, J. H. J. (1994) Antimicrobial activity of lactobacilli: Preliminary characterization and optimization of production of acidocin B, a novel bacteriocin produced by Lactobacillus acidophilus M46. J. Appl. Bacteriol., 77, 140-148.

Cleveland, J., Montville, T. J., Nes, I. F., and Chikindas, M. L. (2001) Bacteriocins: Safe, natural antimicrobials for food preservation. Int. J. Food Microbiol., 71, 1-20.

Du Toit, M., Franz, C. M. A. P., Dicks, L. M. T., and Holzapfel, W. H. (2000) Preliminary characterization of bacteriocins produced by Enterococcus faecium and Enterococcus faecalis isolated from pig faeces. J. Appl. Microbiol., 88, 482-494. 
Enan, G., El-Essawy, A. A., Uyttendaele, M., and Debevere, J. (1996) Antibacterial activity of Lactobacillus plantarum UG1 isolated from dry sausage: Characterization, production and bactericidal action of plantaricin UG1. Int. J. Food Microbiol., 30, 189-215.

Gornall, A. G., Bardwill, G. J., and David, M. M. (1949) Determination of serum proteins by means of biuret reaction. $J$. Biol. Chem., 117, 751-766.

Harrigan, W. F. (1998) Laboratory Methods in Food Microbiology, Academic Press, California, pp. 100-110.

Holzapfel, W. H., Geisen, R., and Schillinger, U. (1995) Biological preservation of foods with reference to protective cultures, bacteriocins and food grade enzymes. Int. J. Food Microbiol., 24, 343-362.

Lindgren, S. W. and Dobrogosz, W. J. (1990) Antagonistic activities of lactic acid bacteria in food and feed fermentations. FEMS Microbiol. Rev., 87, 149-164.

Messens, W. and De Vuyst, L. (2002) Inhibitory substances produced by lactobacilli isolated from sourdoughs-A review. Int. J. Food Microbiol., 72, 31-43.

Muriana, P. M. and Klaenhammer, T. R. (1991) Purification and characterization of Lactacin $\mathrm{F}$, a bacteriocin produced by Lactobacillus acidophilus 11088. Appl. Environ. Microbiol., 57, 114-121.

Rekhif, N., Atrih, A., and Lefebvre, G. (1994) Characterization and partial purification of plantaricin LC74, a bacteriocin produced by Lactobacillus plantarum LC74. Biotechnol. Lett., 16, 771-776.

Samelis, J., Roller, S., and Metaxopoulos, J. (1994) Sakacin B, a bacteriocin produced by Lactobacillus sake isolated from Greek dry fermented sausages. J. Appl. Bacteriol., 76, 475-486.

Saxelin, M. (1997) Lactobacillus GG-A human probiotics strain with thorough clinical documentation. Food Rev. Int., 13, 293-313.

Schagger, H. and Von Jagow, G. (1987) Tricine-sodium dodecyl sulfate-polyacrylamide gel electrophoresis for the separa- tion of proteins in the range from $1-100 \mathrm{kDa}$. Anal. Biochem., 166, 368-379.

Schillinger, U., Geisen, R., and Holzapfel, W. H. (1996) Potential of antagonistic microorganisms and bacteriocins for the biological preservation of foods. Trends Food Sci. Technol., 7, 158-164.

Schillinger, U. and Lucke, F. K. (1987) Identification of Lactobacilli from meat and meat products. Food Microbiol., 4, 199-208.

Scopes, R. K. (1984) Protein Purification-Principles and Practice, Springer Verlag, New York, pp. 52-54.

Stiles, M. E. and Holzapfel, W. H. (1997) Lactic acid bacteria of foods and their current taxonomy. Int. J. Food Microbiol., 36, 1-29.

Suma, K., Misra, M. C., and Varadaraj, M. C. (1998) Plantaricin LP84, a broad-spectrum heat-stable bacteriocin of Lactobacillus plantarum NCIM 2084 produced in a simple glucose broth medium. Int. J. Food Microbiol., 40, 17-25.

Tagg, J. R. and McGiven, A. R. (1971) Assay systems for bacteriocins. Appl. Microbiol., 21, 125.

Todorov, S., Onno, B., Sorokine, O., Chobert, J. M., Ivanova, I., and Dousset, X. (1999) Detection and characterization of a novel antibacterial substance produced by Lactobacillus plantarum ST 31 isolated from sourdough. Int. J. Food Microbiol., 48, 167-177.

van Laack, R. L. J. M., Schillinger, U., and Holzapfel, W. H. (1992) Characterization and partial purification of a bacteriocin produced by Leuconostoc carnosum LA44A. Int. J. Food Microbiol., 16, 181-195.

Yang, R., Johnson, M. C., and Ray, B. (1992) Novel method to extract large amounts of bacteriocins from lactic and bacteria. Appl. Environ. Microbiol., 58, 3353-3359.

Zuniga, M., Pardo, I., and Ferrer, S. (1993) An improved medium for distinguishing between homofermentative and heterofermentative lactic acid bacteria. Int. J. Food Microbiol., 18, 37-42. 